\title{
Implementation Technology for Development of a Brand Communication in Company PT. XYZ
}

\author{
Iskandar Mustofa Nasution ${ }^{1}$, B.P. Kusumo Bintaro², Christien Setiya Kesumawati ${ }^{3}$, \\ Muhamad Zahruddin ${ }^{4}$, Efa Ayu Nabila ${ }^{5}$ \\ Bakrie University, Indonesia ${ }^{1,2}$ \\ University of Raharja, Indonesia ${ }^{3,4,5}$ \\ e-mail: admisi@bakrie.ac.id ${ }^{1}$, kusumo.bintoro@bakrie.ac.id ${ }^{2}$, christien@raharja.info ${ }^{3}$, \\ zahruddin@raharia.info ${ }^{4}$, efaavunabila@raharia.info ${ }^{5}$
}

Nasution , I. M. ., Bintaro, B. K., Kesumawati, C. S. ., Nabila, E. A., \& Zahruddin, M. (2022). The Development Of A Brand Communication Strategy In A Food Catering Service Company Of Pt. Xyz. Aptisi Transactions on Technopreneurship (ATT), 4(1), 17-25.

DOI: https://doi.org/10.34306/att.v4i1.213

\begin{abstract}
The study was conducted at Catering Service Company. The high competition of catering businesses requires the right brand communication strategy to communicate the uniqueness of the catering product in order to increase brand awareness. The purpose of this study is to define the right brand communication strategy by identifying external and internal factors, performing a SWOT analysis, defining segmentation, targeting, and brand positioning. The research approach used is a qualitative and descriptive method with data collection using interviews and document studies. The results of the study show that some competencies possessed by the company can be used as a long-term competitive advantage. While other competencies are competitive equality because they are also owned by competitors. This competitiveness should be communicated well to the target customers. In conclusion, the Type of business for The Catering Company is Business to Business (B2B) for catering services to industrial (factory), training centers, and events, and Business to Consumer (B2C) for wedding catering services. Marketing activities that will be carried out are integrated marketing communication (IMC) through Above the Line (ATL), Below the Line (BTL), and Through the Line (TTL). Brand Communication should be done with more focus and consistency, as well as need a dedicated team to perform brand communication.
\end{abstract}

Keywords: Brand communication strategy, brand awareness, competitive advantage, Integrated Marketing Communication 


\section{Introduction}

The Catering Service Industry is a series of productive activities in the field of providing dishes, both daily dishes, incidental dishes in various banquets, as well as servings at official banquets for various events and moments [1].

Catering is a business that has good prospects, supported by a large number of Indonesians, good economic growth, activity patterns, and changes in the consumption culture of the people. Food and beverages are one of the primary human needs, so catering is one of the profitable business fields and the rate of return on capital is relatively fast, marked by the increasing interest of many parties to work on this business by continuing to increase catering, restaurant, and cafe businesses (Marketing Services). To make this thesis, research was conducted on a catering service company, PT XYZ ("Perusahaan Jasaboga"), a catering service provider company with experience in serving food and beverage dishes since 2012. With a vision, mission, integrity and supported by staff-chef which is professional and experienced in providing catering in large quantities and kitchen facilities complete with good and hygienic cooking utensils to serve products with delicious and fresh taste quality [2], Jasaboga Company continues to develop its performance by marketing its products to the recreational park and non-recreation park markets.

The increasing number of catering service companies has led to a higher level of competition in the catering business. As one way of marketing, it takes the right brand communication strategy to communicate the uniqueness of catering products in order to increase brand awareness of the public as consumers.

Jasaboga companies need to develop a brand communication strategy because the current marketing communications are deemed to be minimal and inconsistent, do not have the right strategy, and do not have a special staff/team focused on creating and implementing brand communication programs as a marketing strategy. By developing a brand communication strategy based on brand identification, analysis of current environmental factors, and analysis of brand segmentation-targeting-positioning, it is expected to be the right marketing strategy to support marketing and increase sales of catering products.

\section{Literature review}

\subsection{Brand}

The American Marketing Association (AMA) defines a brand as a name, term, sign, symbol, or design or a combination of the five components used to identify a product or service and to differentiate it from competitors [3].

\subsection{SWOT Matrix}

Research shows that company performance can be determined by a combination of external and internal environmental factors. SWOT matrix analysis is the identification of various factors systematically to formulate corporate strategy. This analysis is based on the logic that can maximize strengths and opportunities, but simultaneously minimize weaknesses and threats [4].

The SWOT matrix is a tool used to compile the company's strategic factors. This matrix can clearly describe how the external opportunities and threats faced by the company can be adjusted to the strengths and weaknesses it has. This matrix can produce four sets of possible strategic alternatives. 
Tabel 1. SWOT Matrix

\begin{tabular}{|c|c|c|}
\hline & \multicolumn{1}{|c|}{$\begin{array}{c}\text { STRENGTHS (S) } \\
\text { - } \begin{array}{c}\text { Determine 5-10 } \\
\text { internal strength } \\
\text { factor }\end{array}\end{array}$} & $\begin{array}{l}\text { WEAKNESSES (W) } \\
\text { Determine 5-10 factors of } \\
\text { internal weakness }\end{array}$ \\
\hline $\begin{array}{l}\text { OPPORTUNITIES (O) } \\
\text { Determine 5-10 external }\end{array}$ & $\begin{array}{l}\text { STRATEGI SO } \\
\text { Create strategies that use } \\
\text { strengths to take advantage of } \\
\text { opportunities }\end{array}$ & $\begin{array}{l}\text { STRATEGI WO } \\
\text { Create strategies that minimize } \\
\text { opportunities. }\end{array}$ \\
\hline THREATS (T) & STRATEGI ST \\
$\begin{array}{l}\text { Determine 5-10 external threat } \\
\text { factors }\end{array}$ & $\begin{array}{l}\text { Create strategies that use } \\
\text { strength to overcome threats }\end{array}$ \\
\hline
\end{tabular}

The alternative strategies generated as a result of the SWOT matrix analysis are as follows:

a. Strengths-Opportunities (SO) strategy is a strategy that is made based on the company's way of thinking, namely by utilizing all strengths to seize and take advantage of opportunities as much as possible.

b. Strengths-Threats (ST) strategy is a strategy in using the strengths of the company to overcome threats.

c. Weaknesses-Opportunities (WO) strategy is a strategy that is implemented based on the utilization of existing opportunities by minimizing existing weaknesses.

d. Weaknesses-Threats (WT) strategy is a strategy based on activities that are defensive in nature and tries to minimize existing weaknesses and avoid threats

\section{Gambar 2. SWOT analysis}

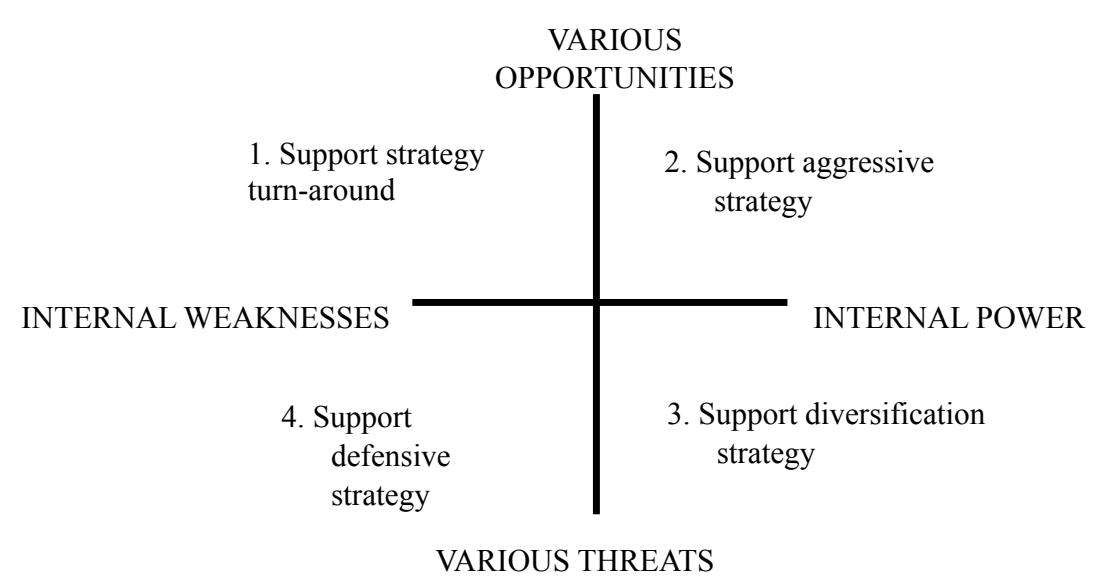

Quadrant 1: This is a very favorable situation. Companies have opportunities and strengths so that they can take advantage of existing 
opportunities. The strategy that must be applied under these conditions is to support an aggressive growth policy (growth-oriented strategy)

Quadrant 2 despite facing various kinds of threats, still has internal strength. The strategy that must be applied is to use strength to take advantage of long-term opportunities by means of a diversification strategy (product/market).

Quadrant 3: the company faces a huge market opportunity but on the other hand faces some internal constraints/weaknesses. The strategy is to minimize internal problems so as to seize better market opportunities.

Quadrant 4: is a very unfavorable situation where you face various kinds of internal threats and weaknesses

\subsection{Relevant Research}

\section{A. Strategy Formulation in Business Units and Marketing of Catering Services Company - Case Study of PT Kaltim Multi Boga Utama, Bontang (Wijayana \& Risanto, 2016)}

Dynamic business competition spurs company managers to be able to think creatively, innovatively in order to always provide differences and advantages for the company compared to its competitors. Companies are required not only to develop good products, offer them at attractive prices, and make them easily accessible to customers in need but also to increase the wants and needs of human life in line with population growth [5].

Strategy formulation and marketing are carried out by conducting qualitative descriptive research, primary data collection techniques, and secondary data in the form of interviews, documentation, participating observation, and through three stages, namely, the Input Stage which consists of the Internal Factor Evaluation (IFE) and External Factor Evaluation (EFE) matrix) [6], Matching Phase which consists of SWOT matrix, Competitive Profile Matrix (CPM), and Grand Strategy matrix which will produce various alternative strategies that can be used by the company and Decision Phase which consists of Quantitative Strategic Planning Matrix (QSPM) matrix which helps in selecting alternative strategies that are suitable for the company's conditions [7].

The results of the analysis with the SWOT matrix and QSPM produce alternative strategies that can be carried out by the company, namely carrying out a market penetration strategy by increasing marketing resources to increase company income, increasing the allocation of funds for company marketing activities, carrying out new promotional activities by offering new promos to the company. customers and improve services by providing guarantees for the products and services offered [8].

a. The suggestions given to companies in developing their business are:

1. Be more aggressive in carrying out marketing strategies by utilizing promotional facilities or by increasing the company's marketing resources.

2. Utilizing technological developments to improve the company's service and service quality.

3. Improving the company's HR management by planning manpower needs.

4. To increase Customer Satisfaction for customers, companies can centralize and maximize Call Center or Customer Service facilities.

5. Create a new name for the company's Wedding Catering services. Build a positive image in the eyes of customers in order to increase customer demand through wedding catering services 
Conclusions based on the formulation of the problem are as follows:

1. The main strength factor is "The quality of the products produced is halal and clean", and being unique (competitive advantage) is difficult for competitors to imitate. The main weakness factor is the "level of income" due to the increase in raw material prices which has led to a reduction in profit margins.

2. The main opportunity factor is "High demand for catering services", which is driven by the current practical cultural trends of urban communities. The threat factor that is very influential is "the number of competitors in the catering service sector" as a result of the increasing demand for catering services.

3. After being analyzed through the EFE, IFE, IE, and QSPM matrices, the main alternative strategy that becomes a priority is "Continuing innovation in order to improve quality and product development to achieve customer satisfaction and loyalty".

\section{Method}

\subsection{Data collection technique}

The techniques used in data collection in the research are interviews and document studies. Company documents include operational documents and product documents. This document study aims to obtain information related to the problem to be studied.

The interview material that will be asked as the opening, content, and closing material ranges from the problem and research objectives, namely brand identification, environmental factors, and related in determining brand communication strategy as a marketing strategy [9]. Active interviews will be conducted in an open way where the interviewee (informant) knows the presence of the interviewer as a researcher by always being tied to the objectives of the interview and having motivation. The interview method is in the form of individual to individual interviews, namely interviews conducted between one person and another. In accordance with the purpose of the interview, the interview respondents consisted of the Director, Chief Marketing \& Operations, and Store Manager. The interview will be conducted using tools/equipment, namely a permit, a list of questions, a list of respondents, block notes, and pens [10] [11].

Table 3. Environmental Factor Analysis - SWOT Matrix

\begin{tabular}{|c|c|c|}
\hline $\begin{array}{l}\text { OPPORTUNITIES } \\
\text { O1. The high demand for } \\
\text { catering services. } \\
\text { O2. The breadth of marketing } \\
\text { coverage. } \\
\text { O3. Increasing people's income } \\
\text { and purchasing power. } \\
\text { O4. Surrounded by big } \\
\text { companies. } \\
\text { O5. The number of corporate events. } \\
\text { O6. Strategic access to } \\
\text { recreational parks. } \\
\text { O7. Widespread media } \\
\text { promotion. }\end{array}$ & $\begin{array}{l}\text { STRENGTH } \\
\text { S1. High quality, halal and } \\
\text { hygienic product } \\
\text { quality. } \\
\text { S2. Supported by qualified } \\
\text { human resources, trained, } \\
\text { friendly attitude, and } \\
\text { appearance in serving food } \\
\text { S3. Competitive prices. }\end{array}$ & $\begin{array}{l}\text { WEAKNESS } \\
\text { W1. The Company's product } \\
\text { branding is not yet } \\
\text { strong. } \\
\text { W2. Promotion strategy to } \\
\text { consumers that have } \\
\text { not been effective. } \\
\text { W3. Marketing personnel } \\
\text { who have not been } \\
\text { optimal. }\end{array}$ \\
\hline
\end{tabular}




\begin{tabular}{|c|c|c|}
\hline $\begin{array}{l}\text { THREATS } \\
\text { T1. The number of competitors and } \\
\text { new companies in the field of } \\
\text { catering services. } \\
\text { T2. Ease of access to product }\end{array}$ & $\begin{array}{l}\text { S1-O1. Maintain service } \\
\text { high-quality catering } \\
\text { S2-O5. Give good service. } \\
\text { S3-O1. Give a price to who can } \\
\text { compete. } \\
\text { S1-O7. Communicating } \\
\text { the strength that the company } \\
\text { has above to the customer. }\end{array}$ & $\begin{array}{l}\text { W1-O2. Strategy } \\
\text { more effective and appropriate } \\
\text { promotion. } \\
\text { W2-07. Develop } \\
\text { effective brand communication. } \\
\text { W3-07. Team building } \\
\text { more reliable marketing. }\end{array}$ \\
\hline $\begin{array}{l}\text { to have more choices and will } \\
\text { be more willing to compare } \\
\text { between one product/brand } \\
\text { with others. }\end{array}$ & $\begin{array}{l}\text { S1-T1. Communicating the } \\
\text { strengths of the } \\
\text { company to } \\
\text { customers. } \\
\text { S1-T2. Upgrade } \\
\text { brand awareness. } \\
\text { S3-T1. Reinforce brand }\end{array}$ & $\begin{array}{l}\text { W2-T2. Strategy } \\
\text { more effective and appropriate } \\
\text { promotion. } \\
\text { W3-T2. Develop } \\
\text { effective brand communication. }\end{array}$ \\
\hline
\end{tabular}

Based on the analysis of environmental factors, analysis of competitive advantage factors, and strategic factors above, the brand communication strategy framework that will be applied in this case study is as follows: 
Gambar 4. Strategy Framework (Strategy Framework)

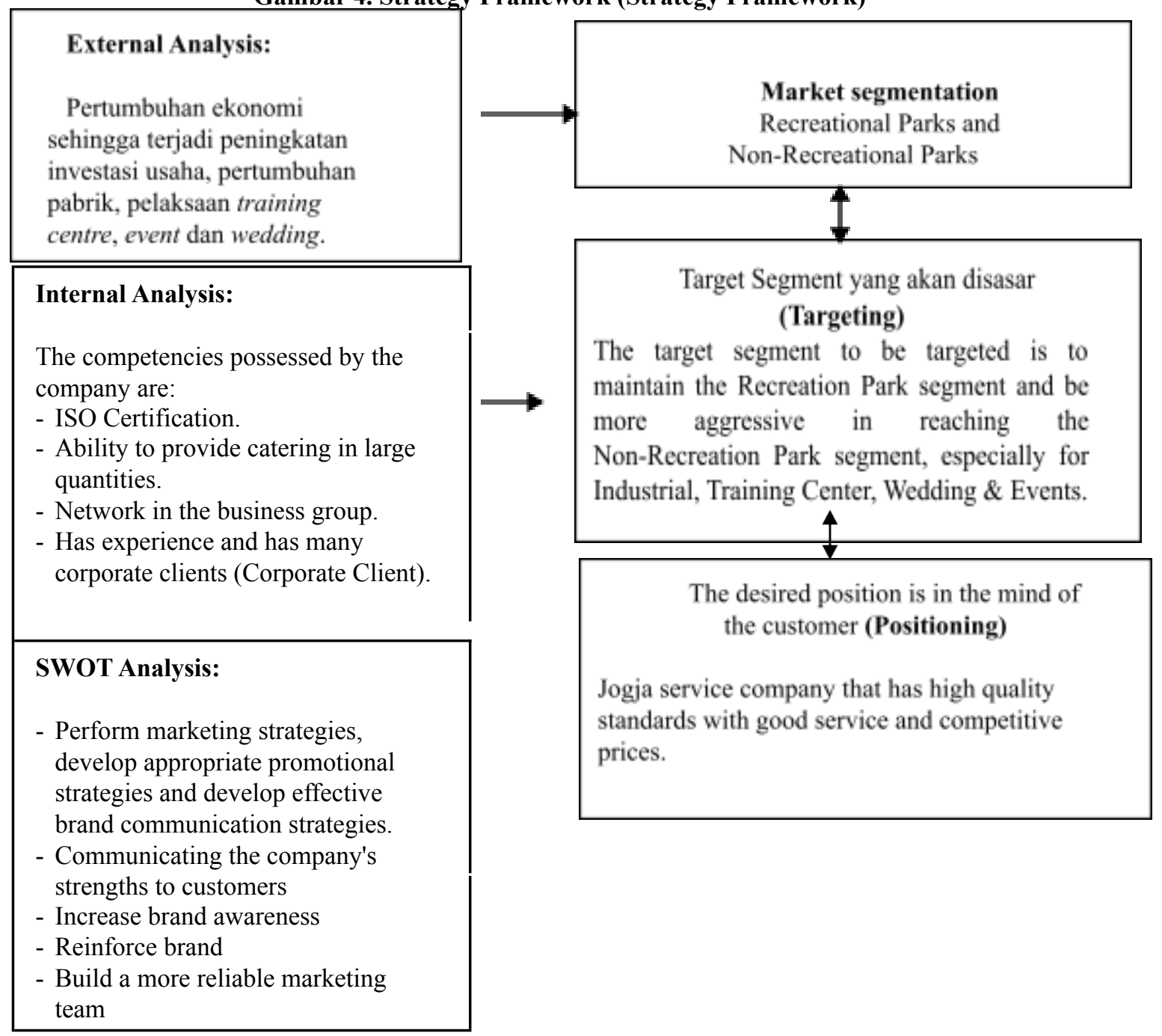

\section{Recommendations And Troubleshooting 1.1Problem}

The service company PT XYZ is not able to compete due to the lack of strong product branding, even though the company has good product and service quality. The lack of strong branding of this product is caused by the lack of effective brand promotion and communication carried out by the Company, so it is necessary to develop a brand communication strategy at Jasaboga Company PT XYZ [12].

\subsection{Problem Solving}

Carry out marketing strategies, develop appropriate promotional strategies and develop effective brand communication strategies, starting from determining STP (Segmentation, Targeting, Positioning), followed by brand communication strategies [13].

1. Segmentation

The market segment to be targeted is the segment for Recreational Parks and Non-Recreational Parks.

2. Target

The target segment to be targeted is to maintain the recreational park segment because it is a source of recurring income and the next target is to be more 
aggressive in reaching the non-recreational park segment, especially to serve the industrial sector, training centers, weddings, and events [14] [15].

3. Positioning

Positioning the desired product in the minds of customers is catering that has high-quality standards with good service and competitive prices.

4. Brand Communication Strategy

The brand communication strategy that will be carried out aims to build brand awareness and communicate product positioning as a caterer that has high-quality standards with good service and competitive prices in the minds of customers [16].

\section{References}

[1] Jang, H., Olfman, L., Ko, I., Koh, J., \& Kim, K. (2008). The influence of online brand community characteristics on community commitment and brand loyalty. International journal of electronic commerce, 12(3), 57-80.

[2] Carlson, B. D., Suter, T. A., \& Brown, T. J. (2008). Social versus psychological brand community: The role of psychological sense of brand community. Journal of business research, 61(4), 284-291.

[3] Fauziah, Z., \& Supriyanti, D. (2021). Influence of Business Process Maturity Model as a Business Architecture Planning Proposal. ADI Journal on Recent Innovation, 2(2), 253-263.

[4] Heikkilä, L., Reinikainen, A., Katajajuuri, J. M., Silvennoinen, K., \& Hartikainen, H. (2016). Elements affecting food waste in the food service sector. Waste Management, 56, 446-453.

[5] Xie, H. Y., \& Boggs, D. J. (2006). Corporate branding versus product branding in emerging markets: A conceptual framework. Marketing Intelligence \& Planning, 24(4), 347-364.

[6] Truong, Y., Klink, R. R., Simmons, G., Grinstein, A., \& Palmer, M. (2017). Branding strategies for high-technology products: The effects of consumer and product innovativeness. Journal of Business Research, 70, 85-91.

[7] Thakor, M. V., \& Pacheco, B. G. (1997). Foreign branding and its effects on product perceptions and attitudes: A replication and extension in a multicultural setting. Journal of Marketing Theory and Practice, 5(1), 15-30.

[8] Valtanen, S. (2021). Co-stitched: Embroidery as a tool for branding: A study through three design commissions.

[9] Hajdas, M., \& Kłeczek, R. (2021). The real purpose of purpose-driven branding: consumer empowerment and social transformations. Journal of Brand Management, $1-15$.

[10] Panjaitan, A. R. S., Rahardja, U., Aini, Q., Santoso, N. P. L., \& Apriliasari, D. (2022). The Management Innovation of Kuliah Kerja Praktek (KKP). APTISI Transactions on Management (ATM), 6(1), 62-73.

[11] Alsharif, A., Tan, C. W., Ayop, R., Dobi, A., \& Lau, K. Y. (2021). A comprehensive review of energy management strategy in Vehicle-to-Grid technology integrated with renewable energy sources. Sustainable Energy Technologies and Assessments, 47, 101439.

[12] Kamel, A. A., Rezk, H., \& Abdelkareem, M. A. (2021). Enhancing the operation of fuel cell-photovoltaic-battery-supercapacitor renewable system through a hybrid energy management strategy. International Journal of Hydrogen Energy, 46(8), 6061-6075. 
[13] Li, M., Wang, L., Wang, Y., \& Chen, Z. (2021). Sizing Optimization and Energy Management Strategy for Hybrid Energy Storage System Using Multi-objective Optimization and Random Forests. IEEE Transactions on Power Electronics.

[14] Purbasari, A., Maryono, G. P., Mulyanto, F., \& Gusdya, W. (2021). Utilization of Google My Business as a Tourism Promotion Media Using Local Search Engine Optimization. IAIC Transactions on Sustainable Digital Innovation (ITSDI), 2(2), 169-178.

[15] LUBIS, A., DALIMUNTHE, R., ABSAH, Y., \& FAWZEEA, B. K. (2021). The Effect of Corporate Communication and Service Quality on Customer Loyalty and Satisfaction in Sharia Banking. The Journal of Asian Finance, Economics, and Business, 8(3), 1267-1274.

[16] Heikal, J., Rialialie, V., Rivelino, D., \& Supriyono, I. A. (2022). Hybrid Model Of Structural Equation Modeling Pls And Rfm (Recency, Frequency And Monetary) Model To Improve Bank Average Balance. Aptisi Transactions on Technopreneurship (ATT), 4(1), 1-8. 